\title{
STABILITAS DERMAGA AKIBAT KENAIKAN MUKA AIR LAUT (STUDI KASUS: PELABUHAN PERIKANAN NUSANTARA PEMANGKAT KALIMANTAN BARAT)
}

\author{
Grecia Alfa, Olga Pattipawaej \\ Jurusan Teknik Sipil, Fakultas Teknik, Universitas Kristen Maranatha \\ Jalan Prof. drg. Suria Sumantri, MPH., no 65, Bandung, 40164 \\ e-mail: olga.pattipawaej@gmail.com
}

\begin{abstract}
ABSTRAK
Perkembangan armada kapal perikanan yang berada di Pelabuhan Perikanan Nusantara (PPN) Pemangkat menunjukkan jumlah yang terus meningkat dengan ukuran kapal yang semakin besar dan kenaikan muka air laut akibat pemanasan global. Analisis lebih lanjut diperlukan untuk struktur dermaga yang sudah ada. Tulisan ini lebih difokuskan kepada stabilitas lereng dermaga akibat pemanasan global menggunakan perangkat lunak Plaxis. Faktor Keamanan untuk stabilitas terhadap penggalian dibagi menjadi dua bagian, yaitu Faktor Keamanan untuk stabilitas terhadap penggalian normal dan Faktor Keamanan untuk stabilitas terhadap penggalian akibat pemanasan global. Faktor Keamanan untuk stabilitas terhadap penggalian, pemancangan, dan pembalokan terdiri dari dua Faktor Keamanan, yaitu untuk stabilitas terhadap penggalian, pemancangan dan pembalokan dalam kondisi normal dan untuk stabilitas terhadap penggalian, pemancangan dan pembalokan dengan memasukkan kenaikan muka air laut akibat pemanasan global. Faktor keamanan yang dihasilkan memperlihatkan bahwa lereng dermaga dalam kondisi stabil.dapat lebih efisien dan aman sesuai kebutuhan pelabuhan.
\end{abstract}

Kata kunci: Dermaga, Pondasi tiang pancang, Stabilitas geoteknik, Kenaikan muka air laut, Plaxis.

\section{PENDAHULUAN}

Peran angkutan laut di Indonesia sebagai negara kepulauan adalah sangat penting. Angkutan barang melalui laut sangat efisien dibanding moda angkutan darat dan udara. Untuk mendukung sarana angkutan laut diperlukan prasarana yang berupa pelabuhan, tempat berlabuh kapal ntuk melakukan berbagai kegiatan seperti menaik-turunkan penumpang, bongkar muat barang, pengisian bahan bakar dan air tawar, melakukan reparasi, dan sebagainya. Pelabuhan ditinjau dari segi penggunaannya berfungsi sebagai pelabuhan ikan, pelabuhan minyak, pelabuhan barang, pelabuhan penumpang, pelabuhan campuran, dan pelabuhan militer. Pelabuhan ikan menyediakan tempat bagi kapal-kapal ikan untuk melakukan kegiatan penangkapan ikan dan memberikan pelayanan yang diperlukan (Triatmodjo, 1999, 2009, dan SPM, 1984).

Perkembangan armada kapal perikanan yang berada di PPN Pemangkat dan sekitarnya selama 5 tahun terakhir menunjukkan jumlah yang terus meningkat dengan ukuran kapal yang semakin besar dan kenaikan muka air laut akibat pemanasan global. Analisis lebih lanjut diperlukan untuk struktur dermaga yang sudah ada. Pada tulisan 
lebih difokuskan kepada analisis stabilitas struktur dermaga menggunakan perangkat lunak Plaxis dengan melakukan pemodelan struktur dan geometri tanah, mendapatkan hasil analisis model dan menentukan kondisi keamanan struktur dermaga. Selain itu analisis yang digunakan sesuai dengan literature yang ada sehingga tidak ada penurunan rumus, analisis ini tidak meninjau analisis biaya, manajemen konstruksi, maupun segi arsitektural, perhitungan tekanan pada tanah disesuaikan dengan data N-SPT, gaya gempa dan tsunami tidak diperhitungkan, parameter kenaikan permukaan air laut akibat pemanasan global merupakan parameter masukan, asumsi permeabilitas tanah arah-x dan-y dianggap sama dan kontrol penulangan tiang pancang tidak dilakukan (Bowles, 1997, Das, 2006 dan Verruijt, 2004).

\section{PERENCANAAN ARUS KOLAM PELABUHAN TERTUTUP}

Arus di kolam pelabuhan rencana didapat dengan menggunakan simulasi arus perairan. Simulasi ini didapat dari perpaduan data PPN Pemangkat dengan meshgrid simulasi seperti pada Gambar 1. Titik pengambilan data untuk time series arus dapat dilihat pada Gambar 2. Gambar 3 dan 4 adalah pola arah dan kecepatan arus kawasan rencana saat pasang dan surut.

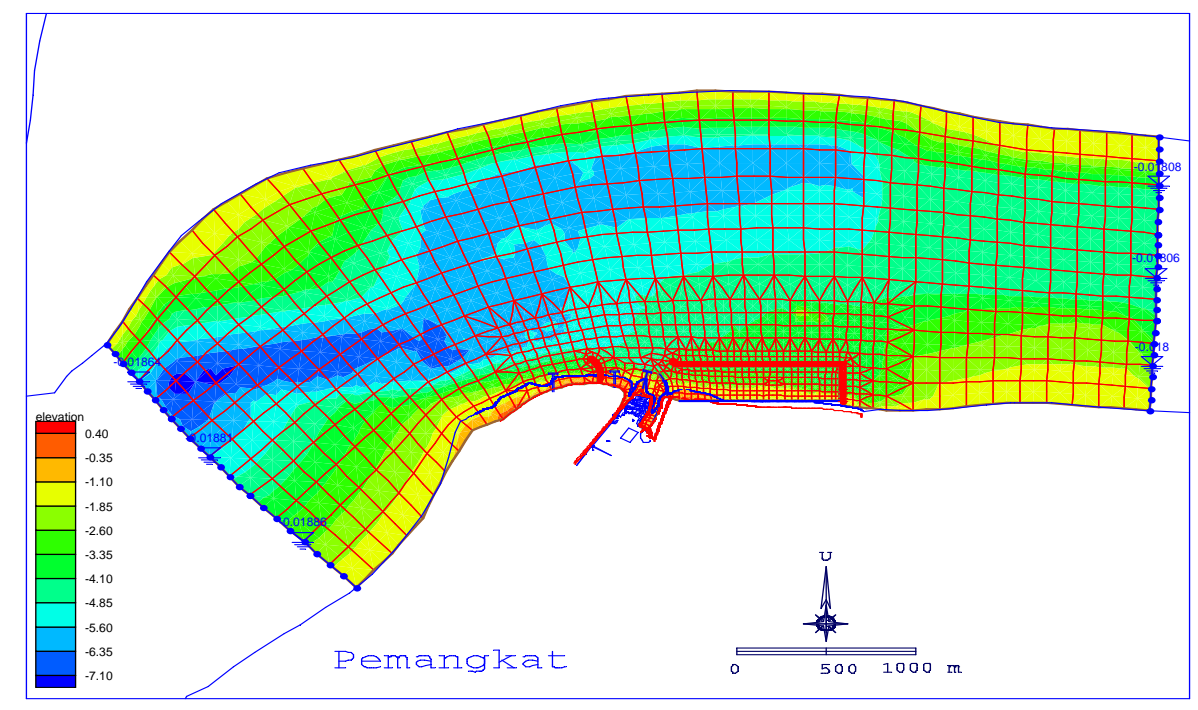

Gambar 1. Mesh Geometri Kawasan Rencana. 


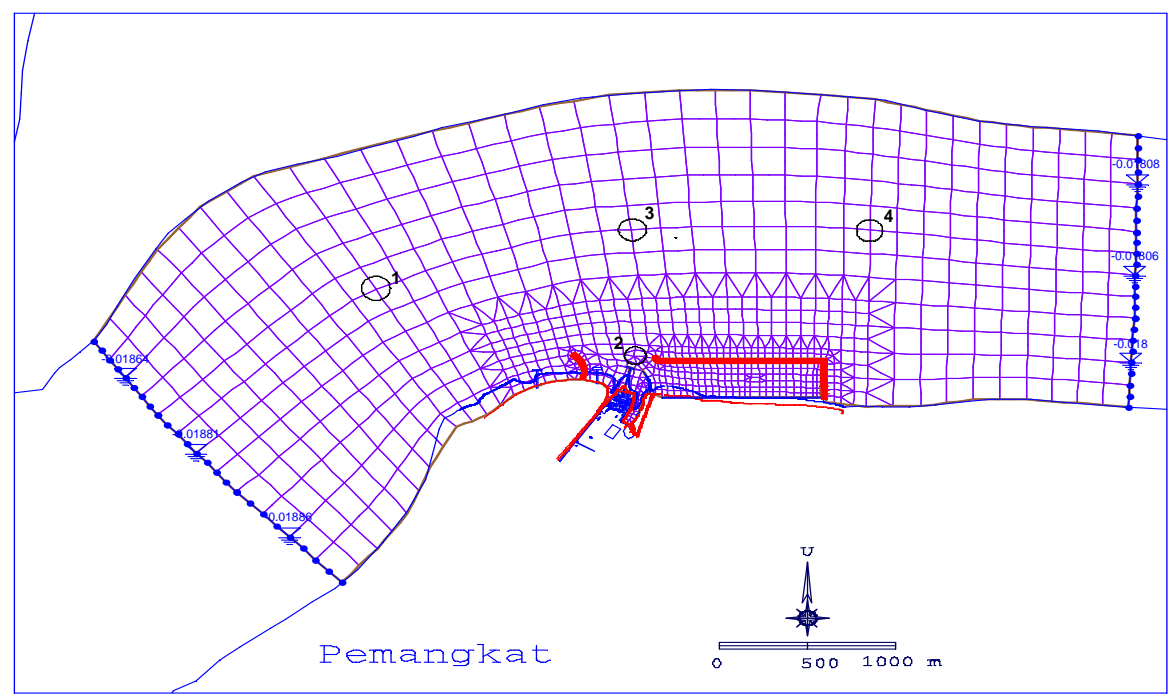

Gambar 2. Titik Pengambilan Data untuk Time Series Arus Kawasan Rencana.

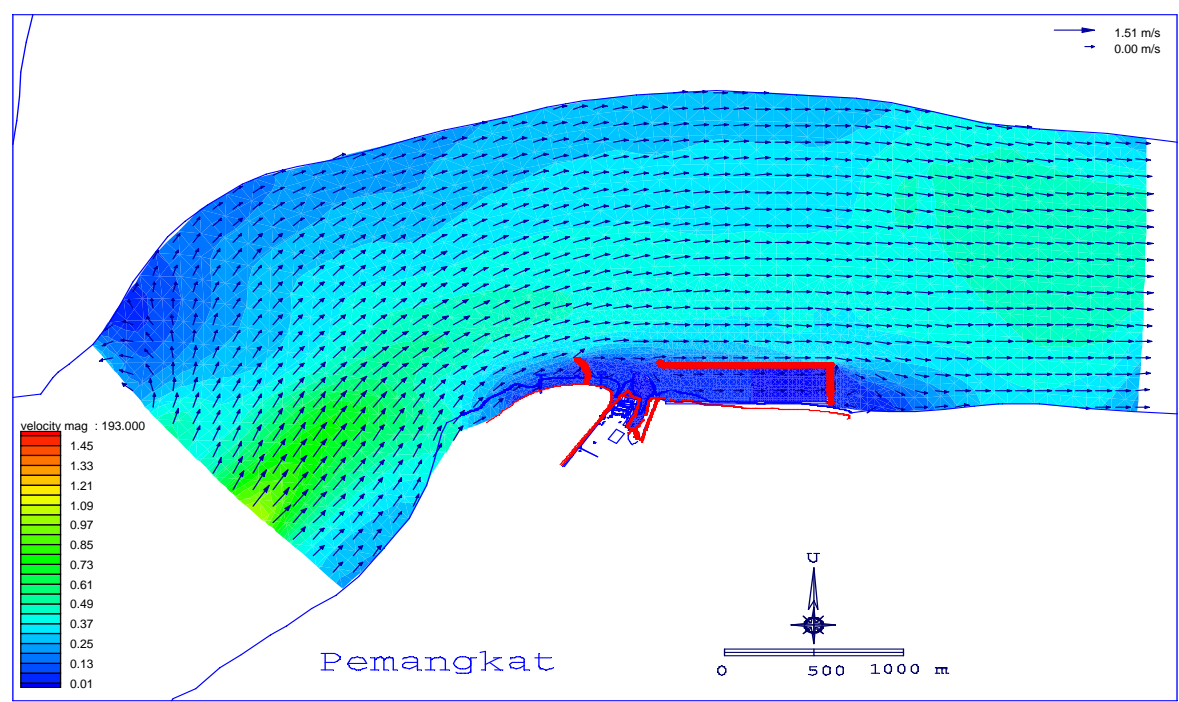

Gambar 3. Pola Arah dan Kecepatan Arus Kawasan Rencana Saat Pasang. 


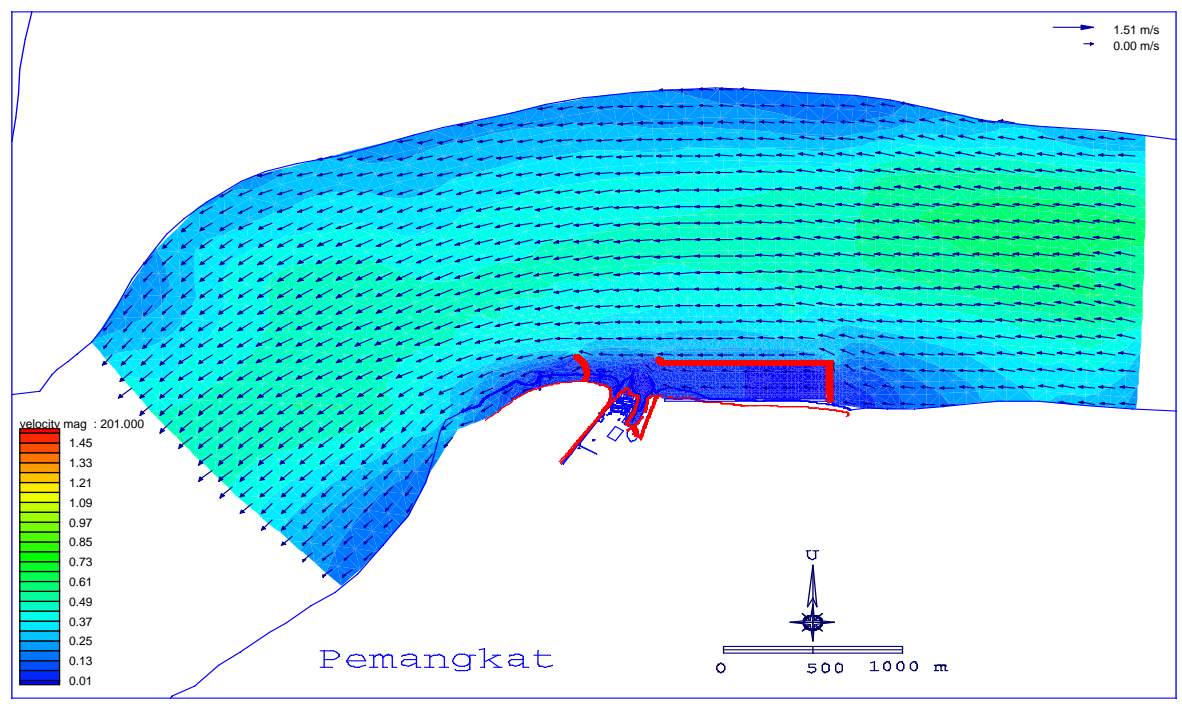

Gambar 4. Pola Arah dan Kecepatan Arus Kawasan Rencana Saat Surut.

Kriteria besar arus yang harus terjadi pada kolam pelabuhan perikanan adalah 1 $\mathrm{m} / \mathrm{dt}$. Simulasi arus untuk kolam pelabuhan mendapatkan hasil $0,5 \mathrm{~m} / \mathrm{dt}$ sehingga lebih kecil dari kriteria desain.

Tekanan angin diasumsikan dengan keadaan lingkungan di Pemangkat, Kalimantan Barat adalah angin kuat, yaitu $P_{\text {angin kuat }}=41 \mathrm{~kg} / \mathrm{m}^{2}$ (Triatmojo, 2009). Untuk kapal lebih dari $100 \mathrm{GT}$, gaya akibat angin yang bergantung kepada tinggi dan draft kapal, diperoleh sebesar $\mathrm{F}_{\text {angin }}=0,994$ ton. Kecepatan arus sebesar $\mathrm{V}_{\text {arus }}=0,15 \mathrm{~m} / \mathrm{det}$, tekanan arus $P_{\text {arus }}=1,18 \mathrm{~kg} / \mathrm{m}^{2}$, dan gaya akibat arus sebesar $\mathrm{F}_{\text {arus }}=0,149$ ton.

Data tiang pancang yang digunakan, yaitu diameter tiang pancang, $\mathrm{D}=0,6 \mathrm{~m}$, panjang tiang pancang terbenan, $\mathrm{L}=30 \mathrm{~m}$, keliling tiang pancang, $\mathrm{P}=1,88 \mathrm{~m}$. Berdasarkan data NSPT, $\mathrm{N}_{\text {SPTRata-rata }}=12,36$ dan berdasarkan metode Meyerhoff diperoleh $\mathrm{Q}_{\mathrm{ult}}=289,40$ ton serta daya dukung ijin sebesar $\mathrm{Q}_{\mathrm{ijin}}=120,58$ ton. Desain pemodelan tiang pancang dermaga yang digunakan adalah panjang tiang di atas muka tanah $-5.8 \mathrm{~m}$, sehingga panjang tiang pancang rencana $35.8 \mathrm{~m}$. Beban yang bekerja: beban mati 28,3 ton (balok dermaga 2,16 ton, pelat dermaga 12 ton, tiang pancang beton 14,14 ton) dan beban hidup sebesar 40 ton, sehingga beban maksimum 1,2 D + 1,6 L sebesar 97,96 ton. Kapasitas daya dukung tiang pancang, yaitu end bearing (Qp) 149,57 ton, total side friction (Qs) 139,83 ton, $\mathrm{Q}_{\mathrm{ult}}=289,40$ ton, dan $\mathrm{Q}_{\mathrm{ijin}}=120,58$ ton. sehingga 120,584 ton $>97,96$ ton, artinya syarat beban maksimum terpenuhi. Dari hasil analisa 
tersebut dapat disimpulkan bahwa kapasitas daya dukung yang ada dapat menahan beban yang bekerja di atas pondasi tiang pancang tersebut.

Beban-beban rencana yang dipakai untuk analisa dihitung sesuai tekanan tanah setiap lapisnya seperti pada Gambar 5 dengan hasil perhitungan tekanan tanah pada lapis $1, \mathrm{P}_{1}=7,00 \mathrm{kN} / \mathrm{m}^{2}$, tekanan pada lapis $2, \mathrm{P}_{2}=32,32 \mathrm{kN} / \mathrm{m}^{2}$, tekanan pada lapis 3 , $\mathrm{P}_{3}=49,18 \mathrm{kN} / \mathrm{m}^{2}$, tekanan pada lapis $4, \mathrm{P}_{4}=67,84 \mathrm{kN} / \mathrm{m}^{2}$, tekanan pada lapis 5 , $\mathrm{P}_{5}=87,85 \mathrm{kN} / \mathrm{m}^{2}$, tekanan pada lapis $6, \mathrm{P}_{6}=107,10 \mathrm{kN} / \mathrm{m}^{2}$, tekanan pada lapis 7 , $\mathrm{P}_{7}=127,40 \mathrm{kN} / \mathrm{m}^{2}$, dan tekanan pada lapis $8, \mathrm{P}_{8}=203,33 \mathrm{kN} / \mathrm{m}^{2}$

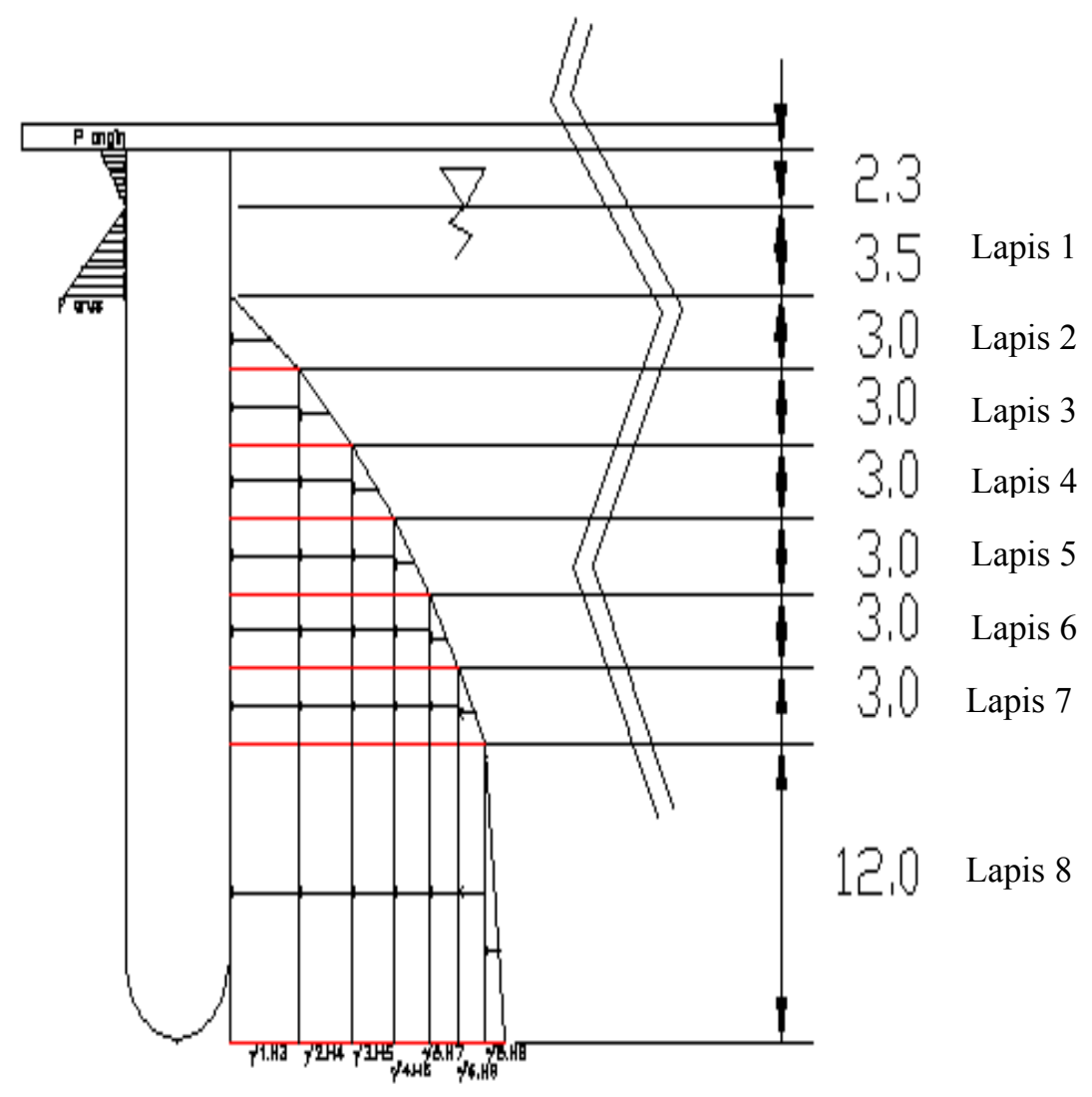

Gambar 5. Diagram Tekanan Angin, Air, dan Tanah.

Beban-beban rencana yang dipakai antara lain: berat pelat dermaga 0,6 ton $/ \mathrm{m}^{2}$ atau $5,89 \mathrm{kN} / \mathrm{m}^{2}$, beban balok dermaga $0,43 \mathrm{ton} / \mathrm{m}^{2}$ atau $4,24 \mathrm{kN} / \mathrm{m}^{2}$, dan berat tiang pancang 14,14 ton atau $138,71 \mathrm{kN}$, serta beban hidup (maksimum) 2 ton $/ \mathrm{m}^{2}$ atau 19,62 $\mathrm{kN} / \mathrm{m}^{2}$, sehingga beban total untuk pelat sebesar $29,74 \mathrm{kN} / \mathrm{m}^{2}$. 


\section{ANALISIS STABILITAS DERMAGA MENGGUNAKAN PLAXIS}

\subsection{Kestabilan Lereng Tanpa Pemancangan Tiang dengan Beban Air Sepanjang Dermaga}

Dengan menggunakan bantuan perangkat lunak Plaxis, kestabilan lereng tanpa beban dan tanpa perkuatan geotextile dibagi menjadi dua phase, phase 1 (General Calculation, calculation type yang dipilih adalah plastic dan load adv.ultimate level. Setelah general calculations, kemudian masuk ke parameters calculation. Pada tahap ini, masukan beban atau loading input sesuai tahapan yang diinginkan, dalam hal ini pilih Stage Construction.

Multipliers calculation adalah tahapan memasukan beban, kestabilan lereng yang akan dihitung pada kondisi ini adalah tanpa pemancangan tiang dan ada beban air sepanjang dermaga, dan phase 2 (dalam tahap ini stage construction telah selesai, untuk kemudian akan dihitung faktor keamanan, sebelumnya pada calculation type yang dipilih adalah load adv.number of step.

Parameters calculation untuk phase 2 ini adalah tahapan menghitung faktor keamanan, Plaxis secara otomatis akan memilih sendiri loading input yaitu phi/c reduction, karena pada tahap general calculation telah dipilih load adv.number of step).

Setelah perhitungan selesai dilakukan, hasilnya dapat dilihat pada bagian output yang terlihat pada toolbar. Untuk angka keamanan dapat langsung dilihat pada Multipliers, kemudian $\Sigma$-Msf. Hasil perhitungan stabilitas lereng tanpa pemancangan tiang dan ada beban air sepanjang dengan menggunakan program Plaxis didapat $\Sigma$-Msf = 1,8579 .

Ini berarti lereng tersebut sangat aman, karena standar nilai faktor keamanan lereng adalah $\mathrm{FK} \geq 1,2$. Selain $\Sigma$-Msf, dalam output juga dapat dilihat perpindahan dan tegangan-tegangan yang terjadi. Arah tegangan yang terjadi dapat dilihat pada Gambar 6 .

Stabilitas Dermaga Akibat Kenaikan Muka Air Laut (Studi Kasus: Pelabuhan Perikanan 


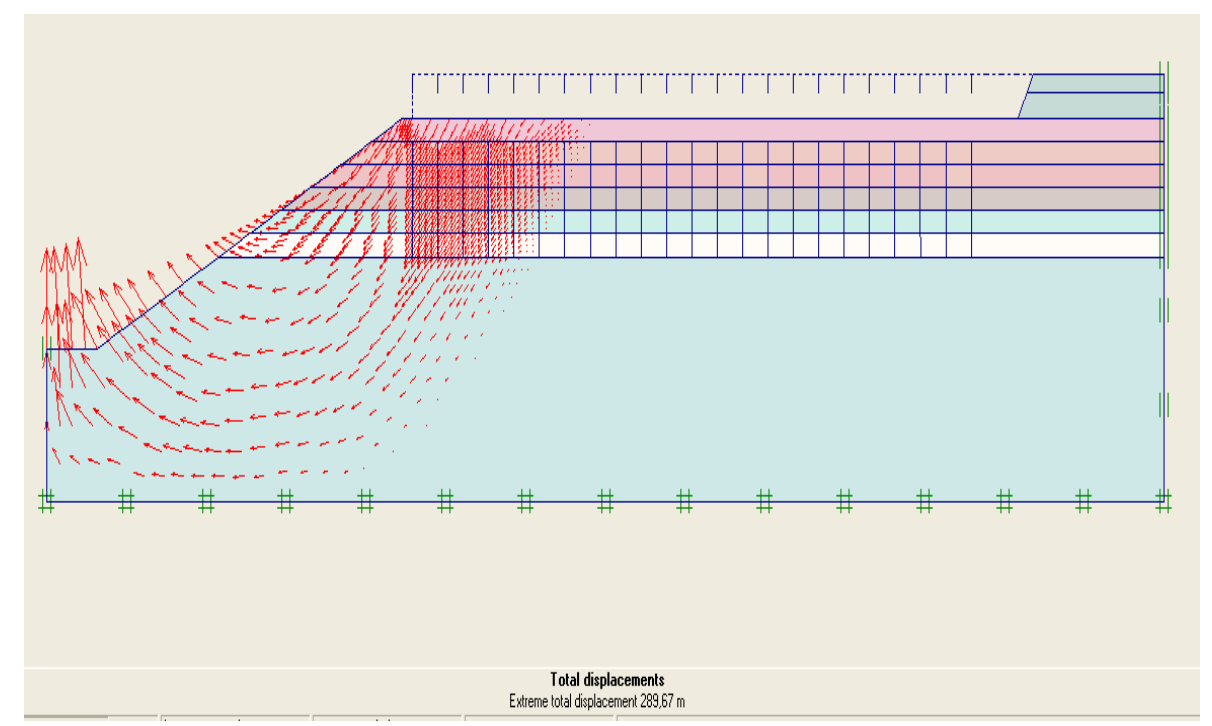

Gambar 6. Arah Tegangan yang Terjadi.

\subsection{Kestabilan Lereng dengan Seluruh Konstruksi pada Plaxis}

Langkah-langkah pemodelan analisa stabilitas timbunan menggunakan program Plaxis: pada saat membuka Plaxis Input, sebuah kotak dialog Creat/Open project akan ditampilkan. Pilih option New Project pada kotak dialog tersebut kemudian tekan tombol $<\mathrm{OK}>$ untuk membuat Project baru.

Setelah kotak dialog General settings ditampilkan, pada lembar tab Project masukkan nama proyek pada kotak Title. Pilih Model Axisymmetry dan Element 15-Node. Satuan panjang, gaya, dan waktu yang digunakan adalah $\mathrm{m}, \mathrm{kN}$, dan hari, maka pada combo box Length, Force, dan Time berturut-turut dipilih m, kN, dan day, serta masukkan data geometri dan data grid yang akan digunakan.

Pada saat jendela Plaxis Input ditampilkan, gambar model geometri yang akan dianalisa seperti pada Gambar 7 dengan menggunakan Geometry line dan pemodelan tiang pancang seperti pada Gambar 8. Pengaplikasian Standard fixities pada model geometri dapat dilihat pada Gambar 9.

Setelah boundary condition untuk model geometri terbentuk, langkah berikutnya adalah pengidentifikasian dan pengaplikasian data tanah dan geotekstil pada model geometri . Interface adalah daerah interaksi antara permukaan material (tanah) dengan material lain (baja, beton, kayu, dll). Pilihan rigid berarti kekuatan material di daerah interface tetap (tidak terganggu), sementara pilihan manual berarti ada gangguan yang menyebabkan penurunan kekuatan tanah di daerah interface. Sedangkan R-inter adalah faktor reduksi besar kekuatan tanah pada daerah interface jika option (Manual) diambil. For guidance: $R$-inter = 0,5 (clay - steel), 0,67 (sand - steel), 0,75 (clay-concrete), 0,8 
- 1,0 (sand - concrete). Kemudian $\delta$-inter merupakan tebal daerah interface. Langkah selanjutnya dilakukan aplikasi data tanah pada model geoetri seperti pada Gambar 10.

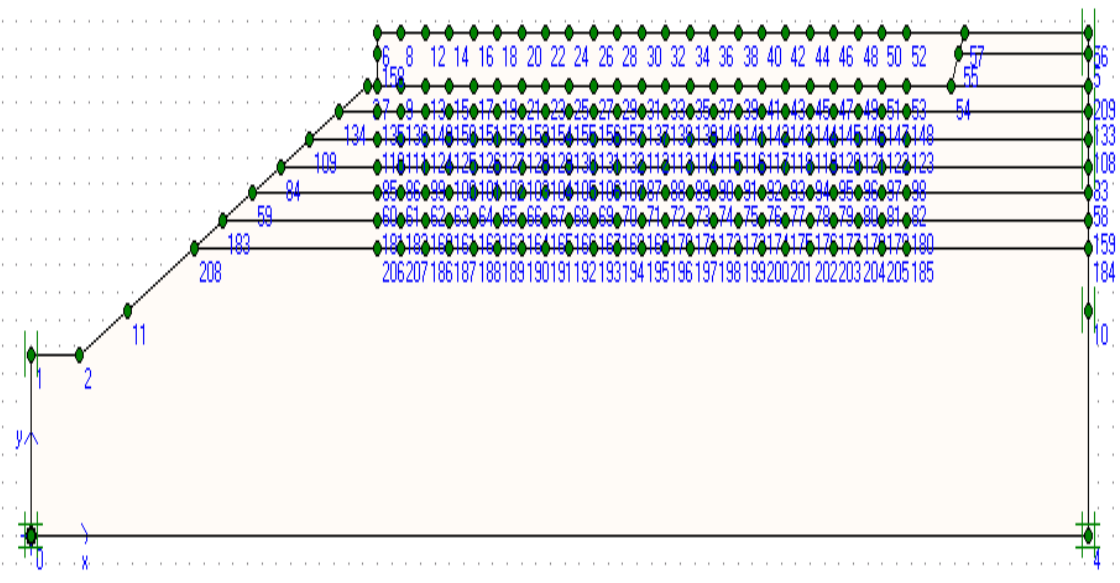

Gambar 7. Pemodelan Geometri Tanah.

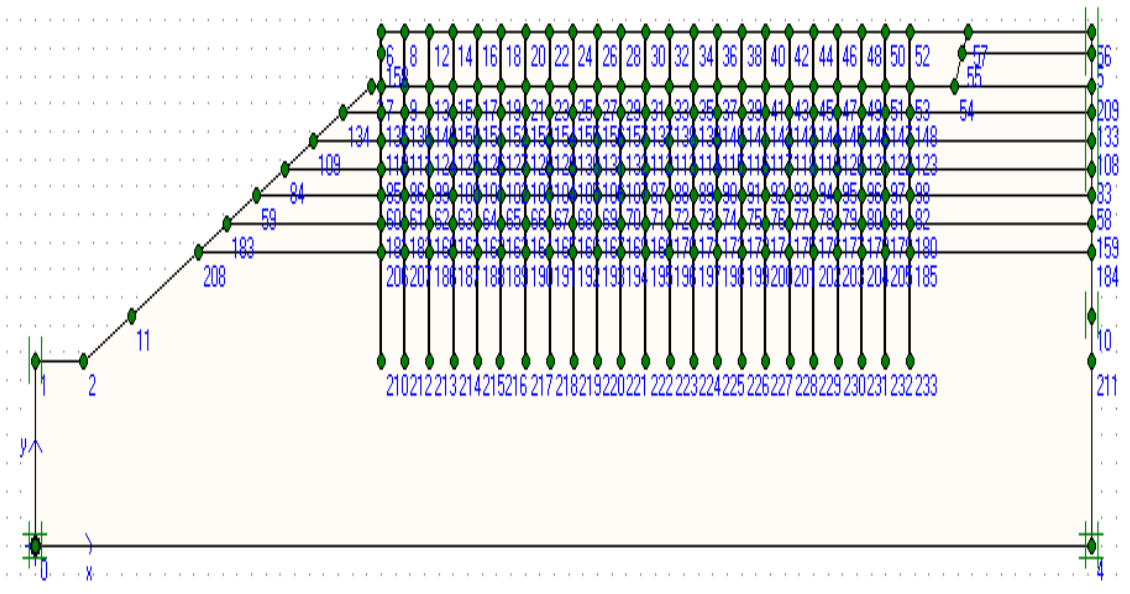

Gambar 8. Pemodelan Tiang Pancang. 


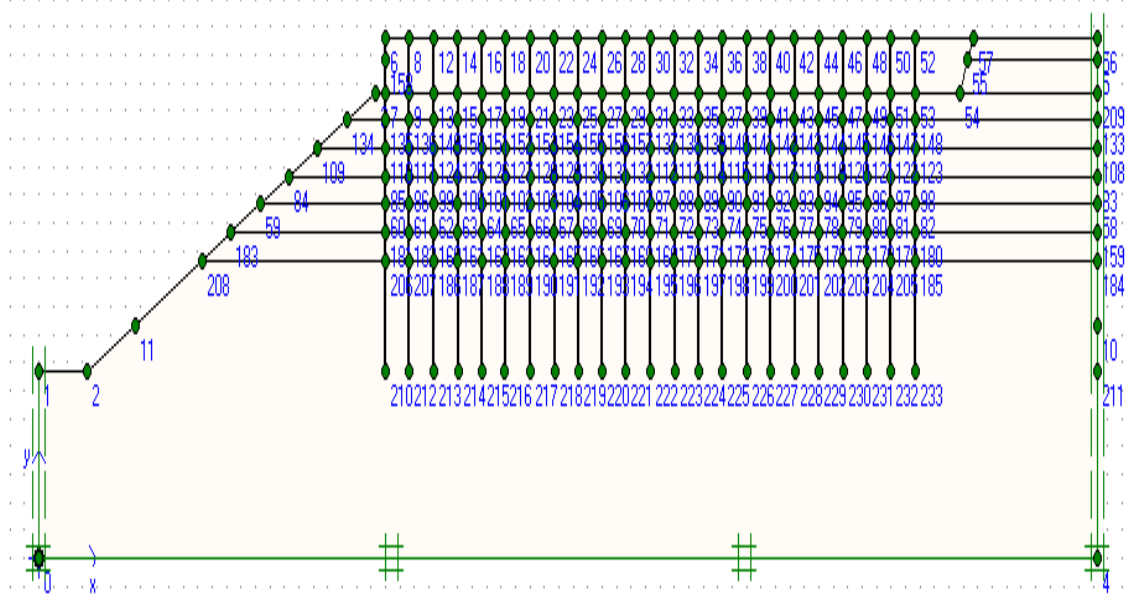

Gambar 9. Pengaplikasian Standard fixities pada Model Geometri.

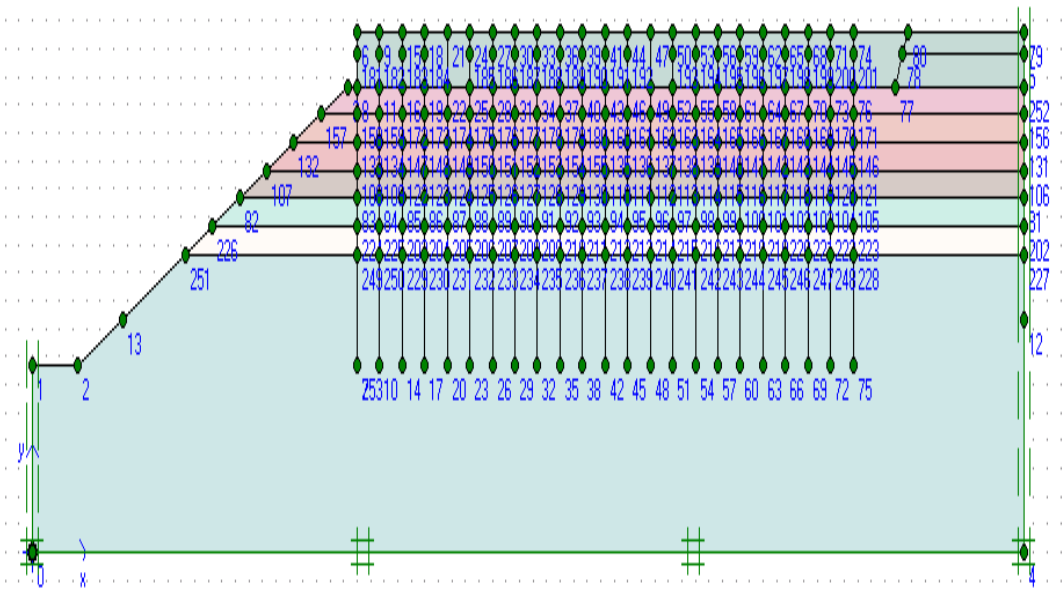

Gambar10. Pengaplikasian Data Tanah pada Model Geometri.

Selanjutnya adalah memberi keterangan jenis pembebanan dan besarnya. Pada kasus ini hanya ada satu pembebanan merata. Posisikan pembebanan seperti menggambar geometri atau bisa juga dengan memasukkan koordinat pembebanannya (Gambar 11). 


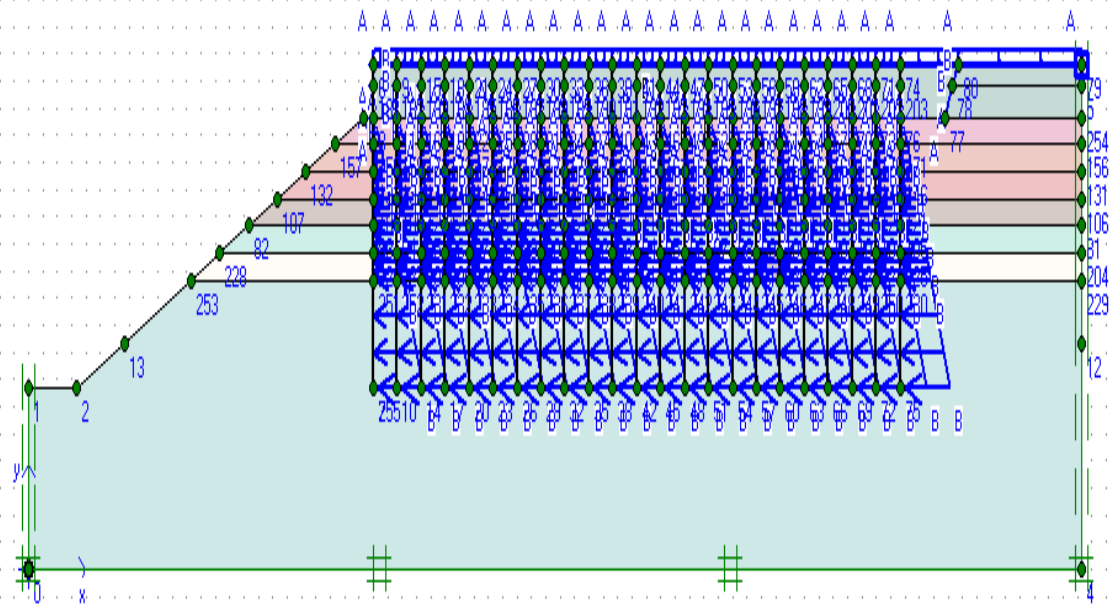

Gambar 11. Pemodelan Beban pada Tiang Pancang dan Balok.

Untuk memberi nilai besarnya pembebanan, maka dapat meng-klik pada garis beban, contohnya seperti Gambar 12.

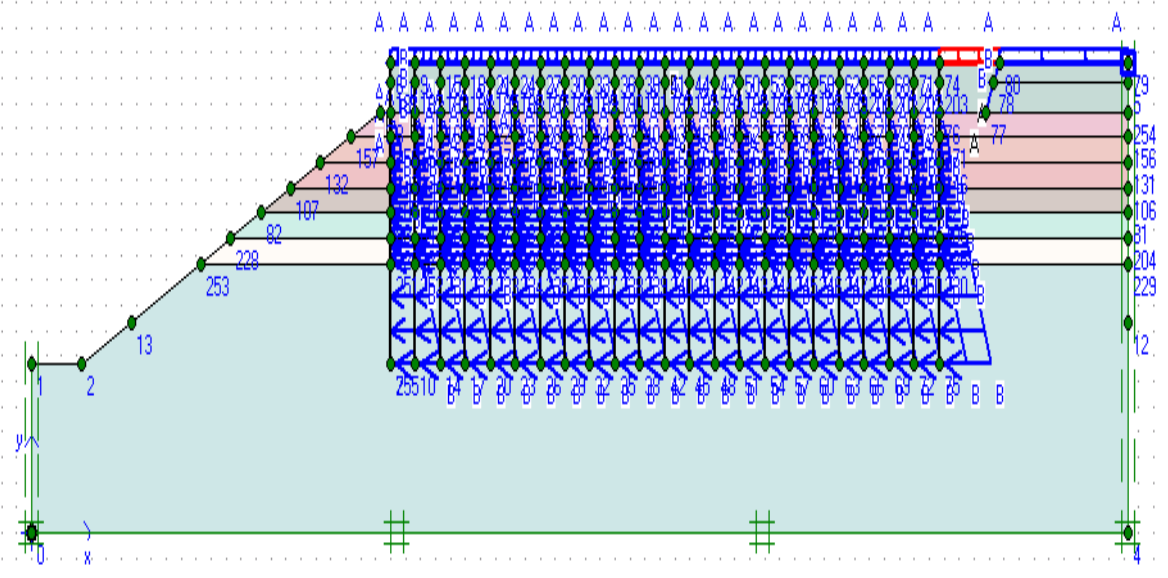

Gambar 12. Pemodelan Beban.

Setelah pendefinisian dan pengaplikasian data material selesai dilakukan, tahapberikutnya adalah membuat jaring elemen hingga pada model geometri. Sehingga akan muncul hasil seperti pada Gambar 13. 


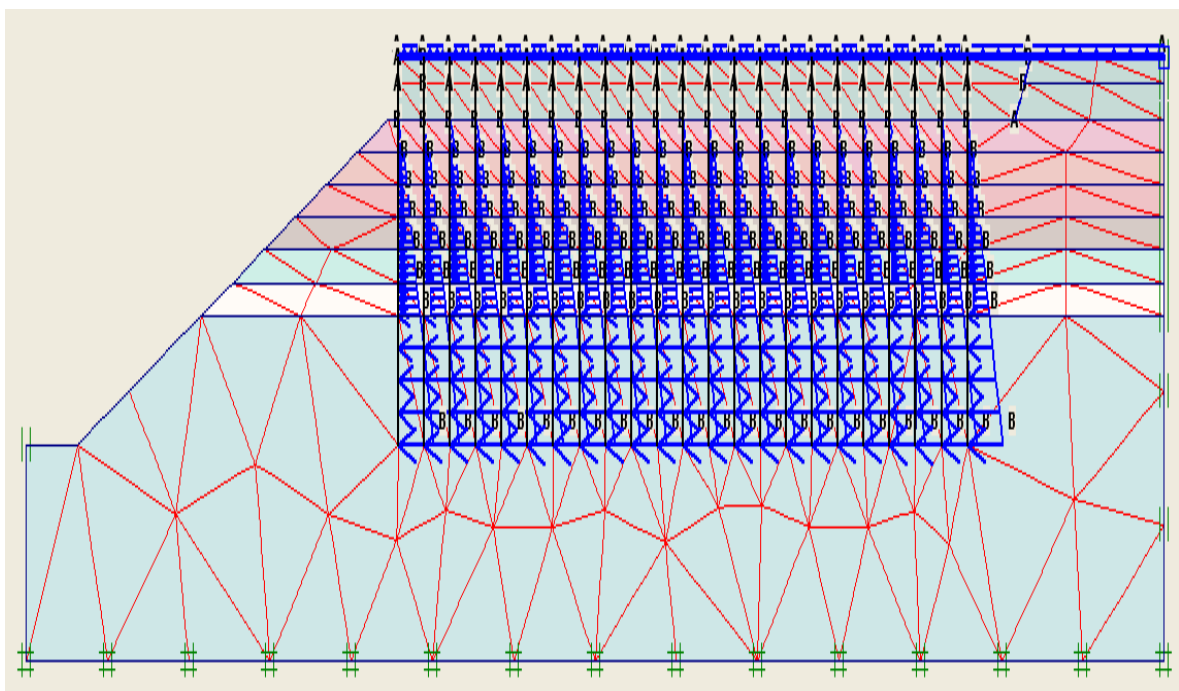

Gambar 13. Output Setelah Generate Mesh pada Lapisan Tanah.

Pada bagian ini harus didefinisikan kondisi awal, dimana belum ada galian dan perkuatan. Sehingga akan muncul seperti Gambar 14.

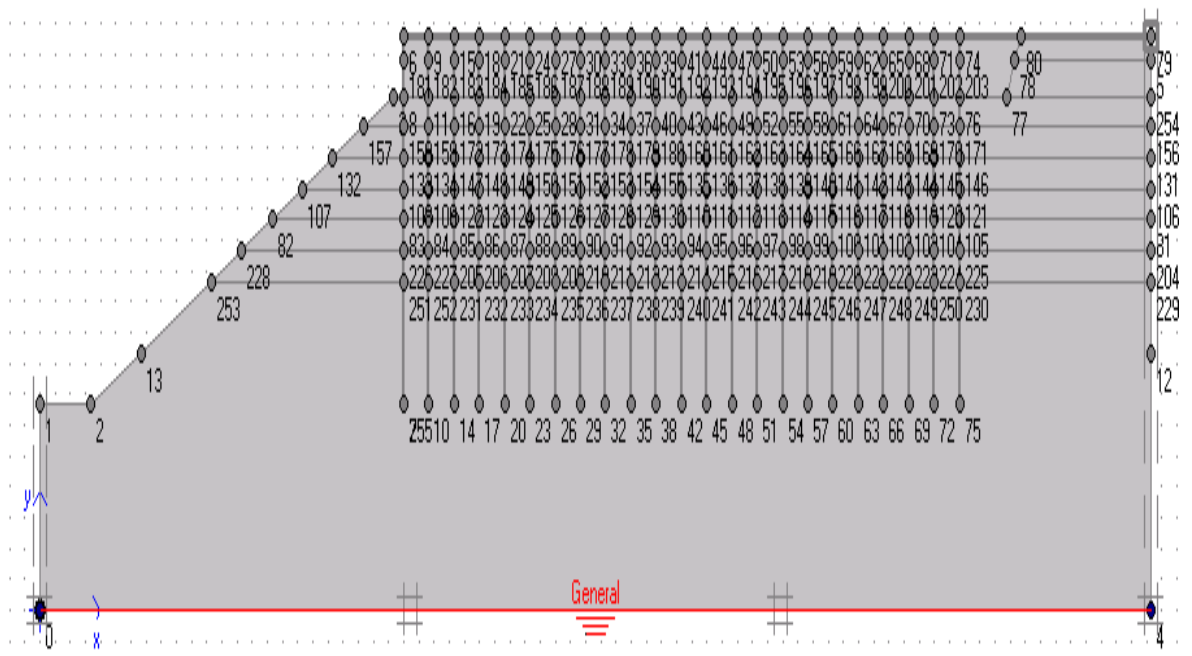

Gambar 14. Pendefinisian Kondisi Awal Tanah pada Perangkat Lunak Plaxis.

Pendefinisian muka air tanah pada 53,50 menggunakan phreatic level dapat dilihat pada Gambar 15. Gambar 16 menunjukkan besar tekanan air tanah yang bekerja. 


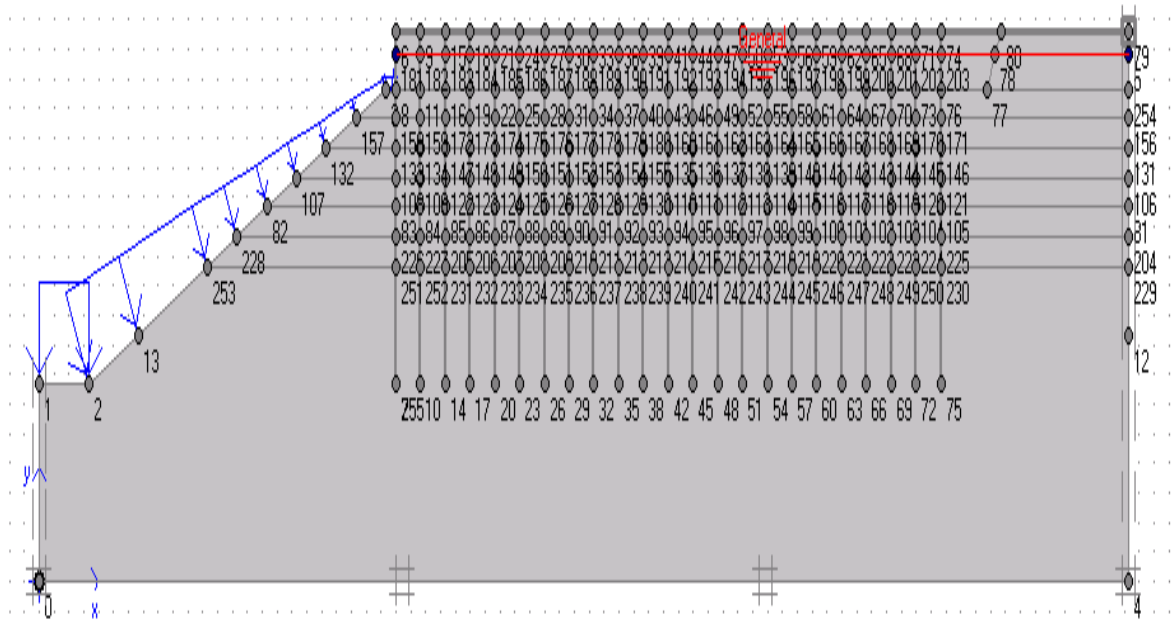

Gambar 15. Pendefinisian Muka Air Tanah pada Perangkat Lunak Plaxis.

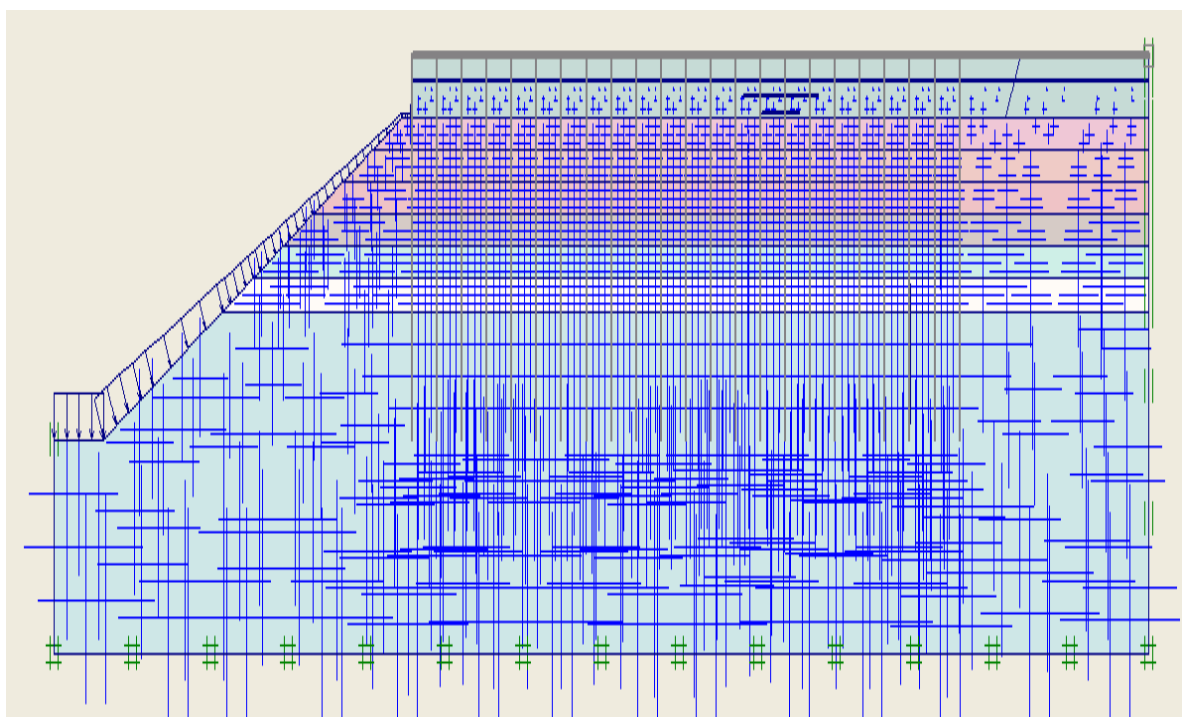

Gambar 16. Tekanan Air Pori Sesuai Output Plaxis.

Gambar 17 adalah pemodelan tanah asli sebelum penggalian dan pemancangan. Tegangan efektif tanah dasar yang bekerja dapat dilihat pada Gambar 18. 


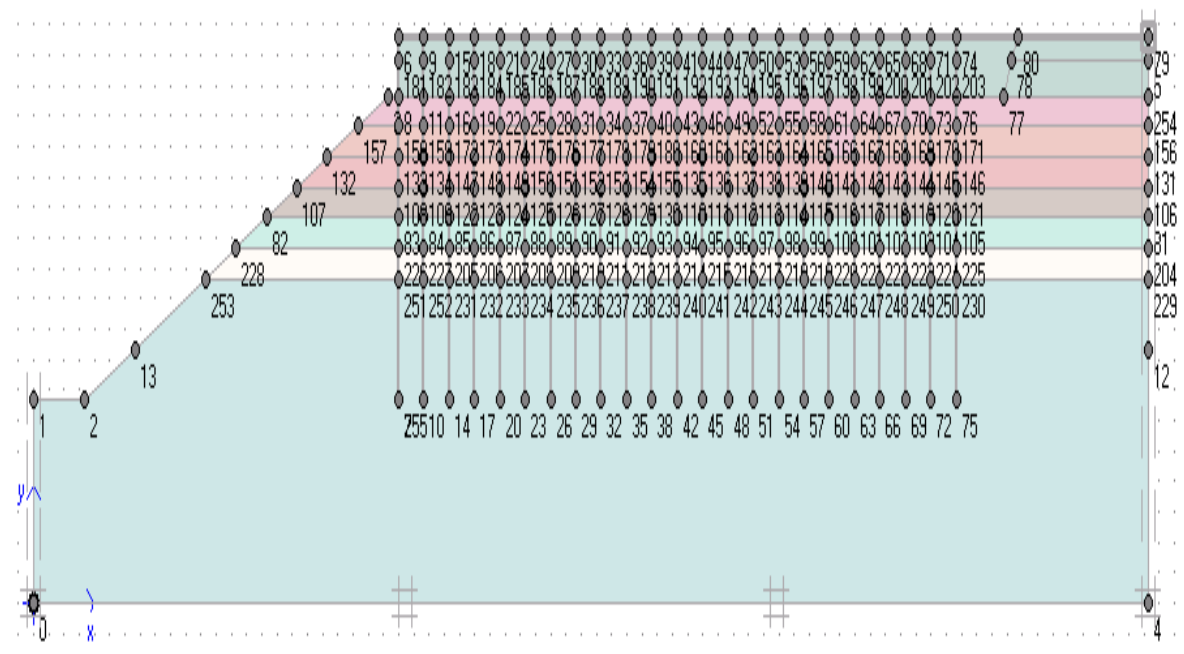

Gambar 17. Tanah Asli sebelum Penggalian dan Pemancangan.

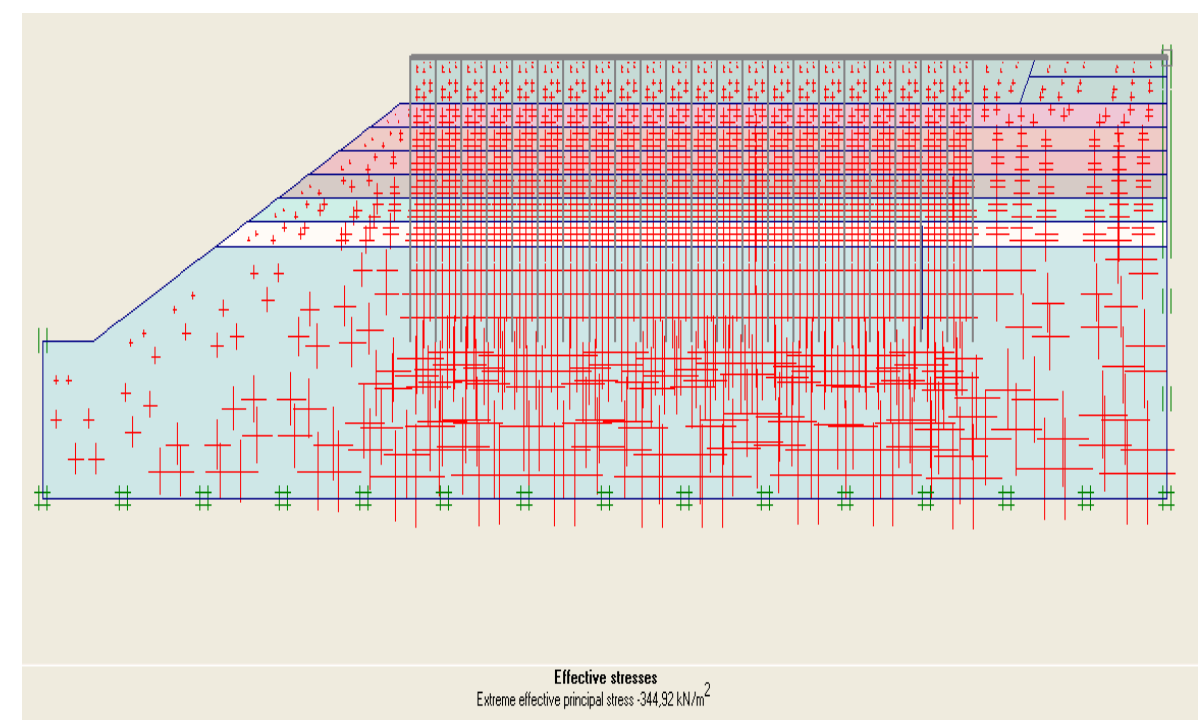

Gambar 18. Tegangan Efektif Tanah Dasar yang Bekerja.

Setelah proses penggalian dapat dilihat pada Gambar 19. 


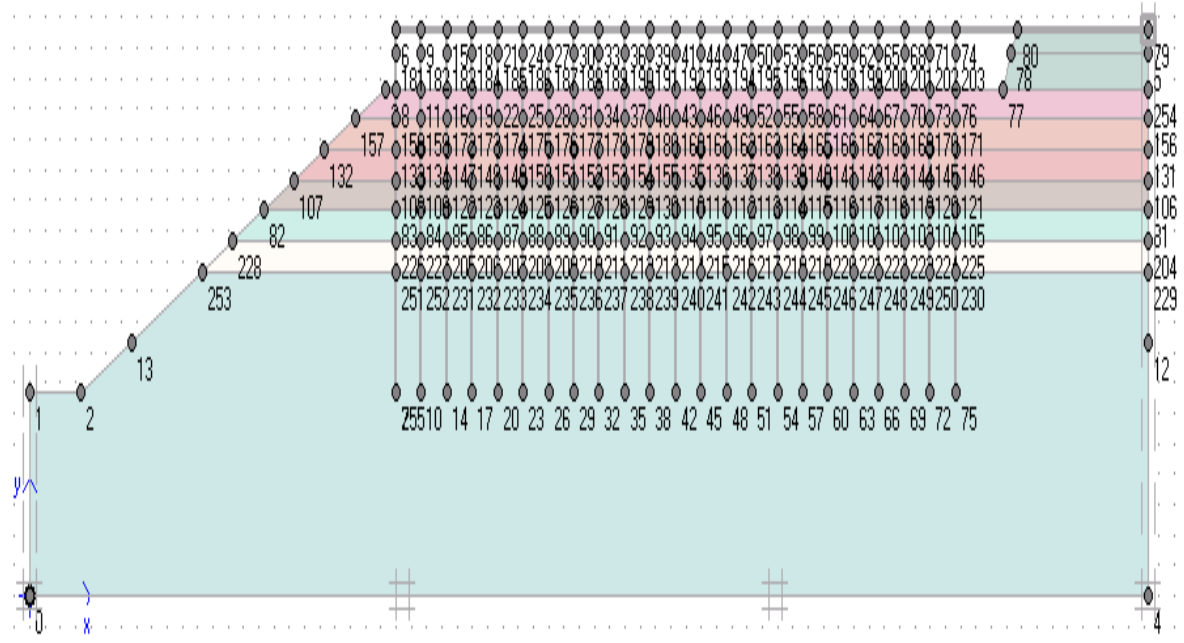

Gambar 19. Setelah Proses Penggalian.

Plaxis berbasis pada konstruksi bertahap, maka harus didefinisikan tahap konstruksi dari mulai timbunan awal, pondasi untuk facing, perkuatan geogrid dari langkah awal hingga langkah akhir. Gambar 20 menunjukkan tahapan konstruksi setelah proses penggalian, pemancangan, dan pembalokan. Output deformasi tanah, tiang pancang, dan balok dapat dilihat pada Gambar 21.

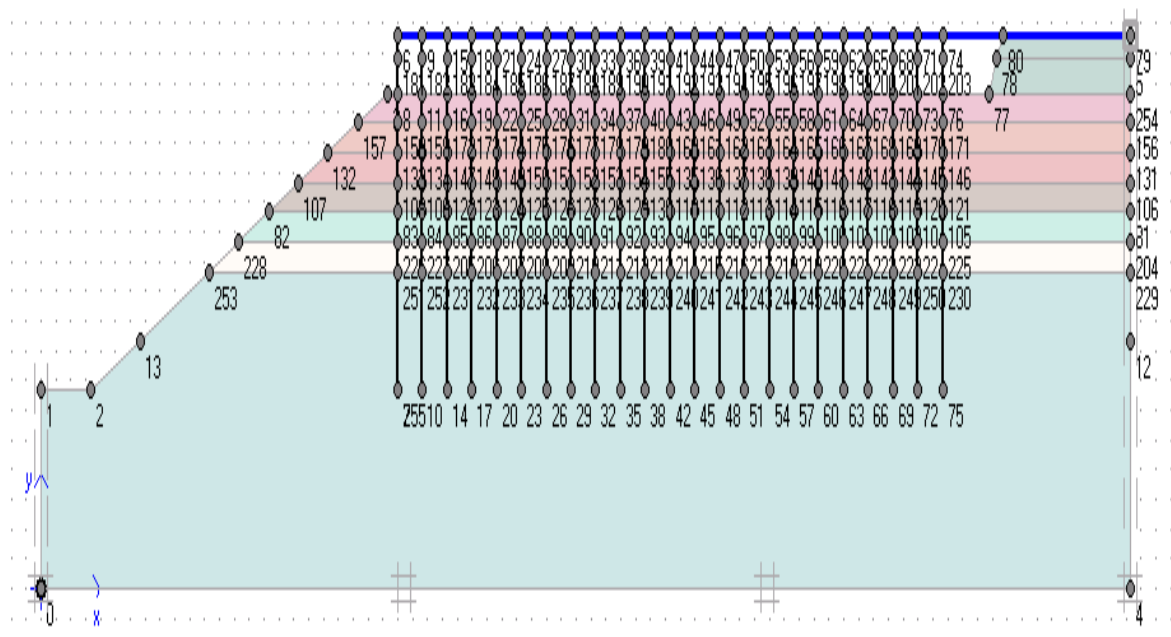

Gambar 20. Setelah Proses Penggalian, Pemancangan, dan Pembalokan. 


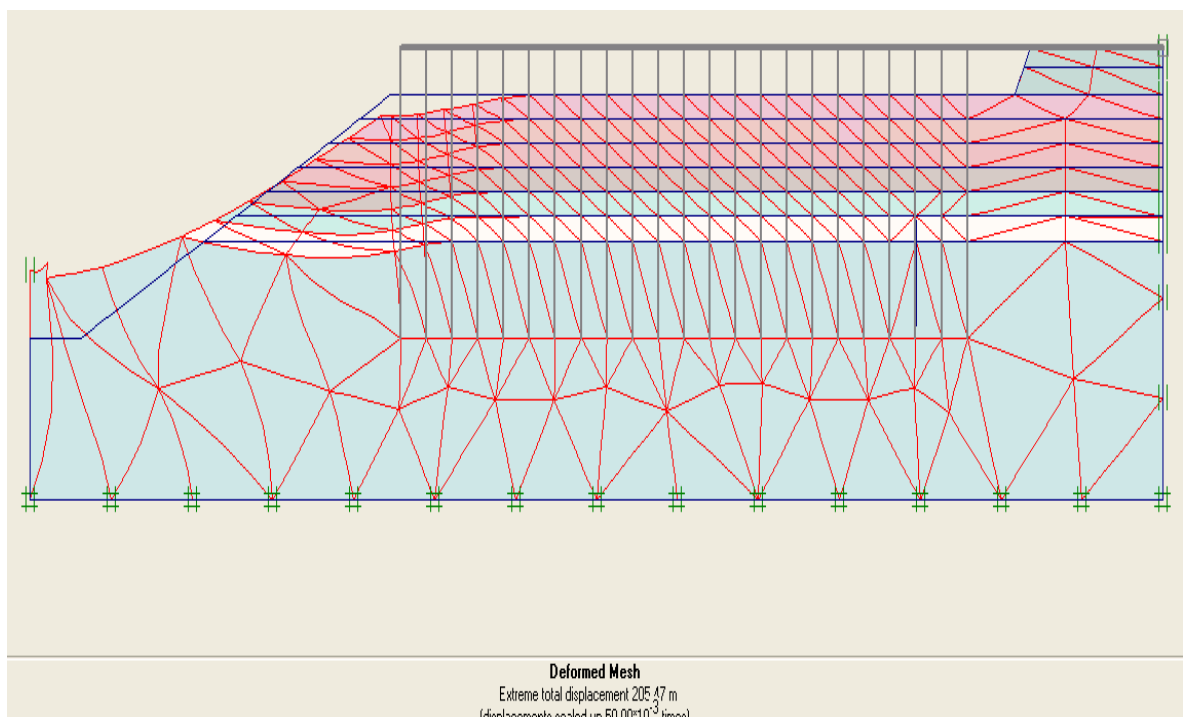

Gambar 21. Output deformasi Tanah, Tiang Pancang, dan Balok.

Berdasarkan output, nilai total pergeseran ekstrim dalam keadaan normal adalah 205,47 m. Faktor keamanan untuk stabilitas lereng terhadap penggalian dan beban air laut sebesar 1,8579. Faktor keamanan untuk stabilitas terhadap penggalian untuk keadaan normal diperoleh 2,3235 dan faktor keamanan untuk stabilitas terhadap pemancangan dan pembalokan saat kondisi normal sebesar 2,3478.

Perpindahan dan tegangan dan regangan yang terjadi terlihat pada Gambar 22. Gambar 23 menunjukkan arah keruntuhan yang terjadi pada keadaan normal 


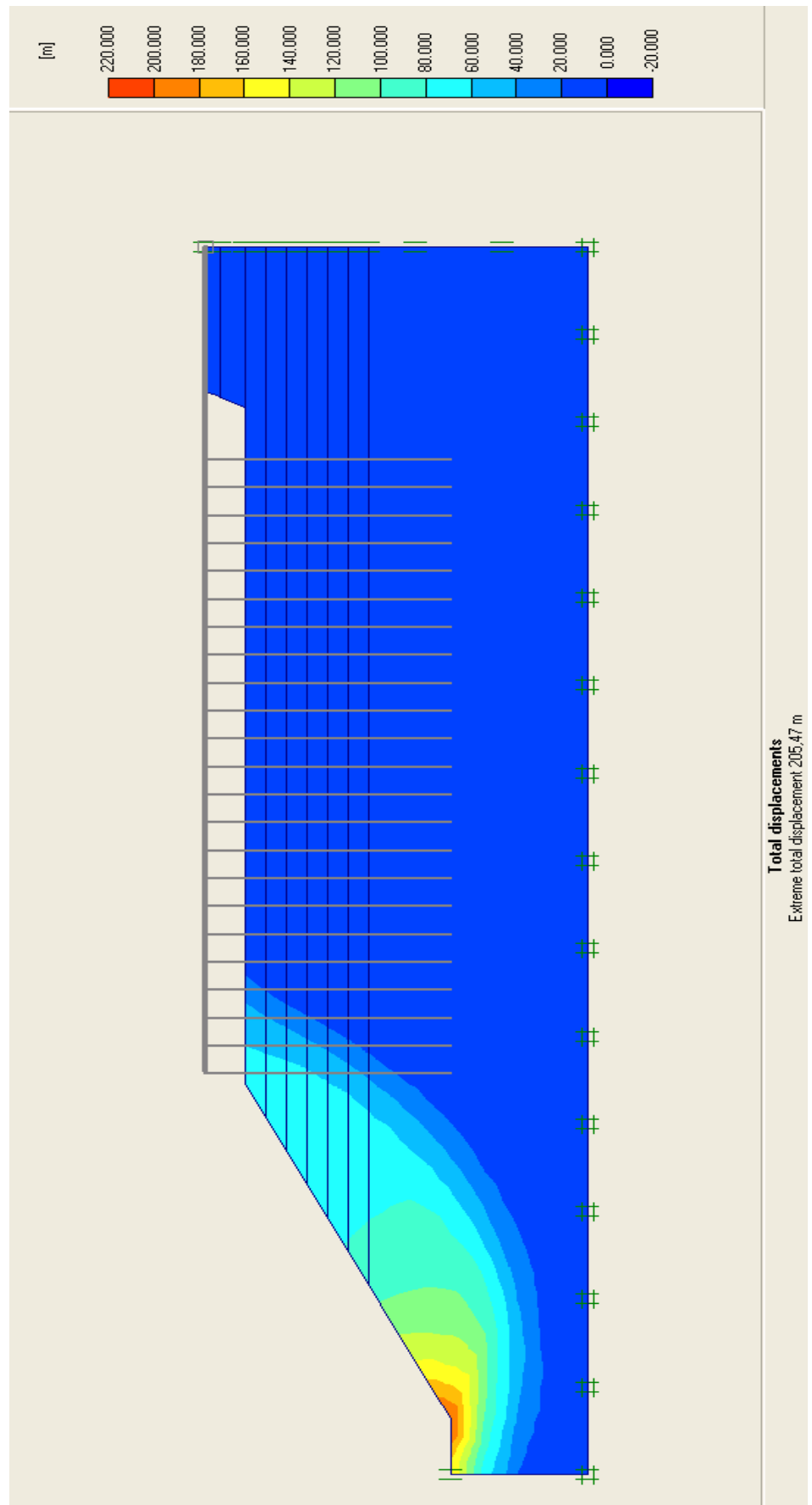

Gambar 22. Output deformasi Tanah. 


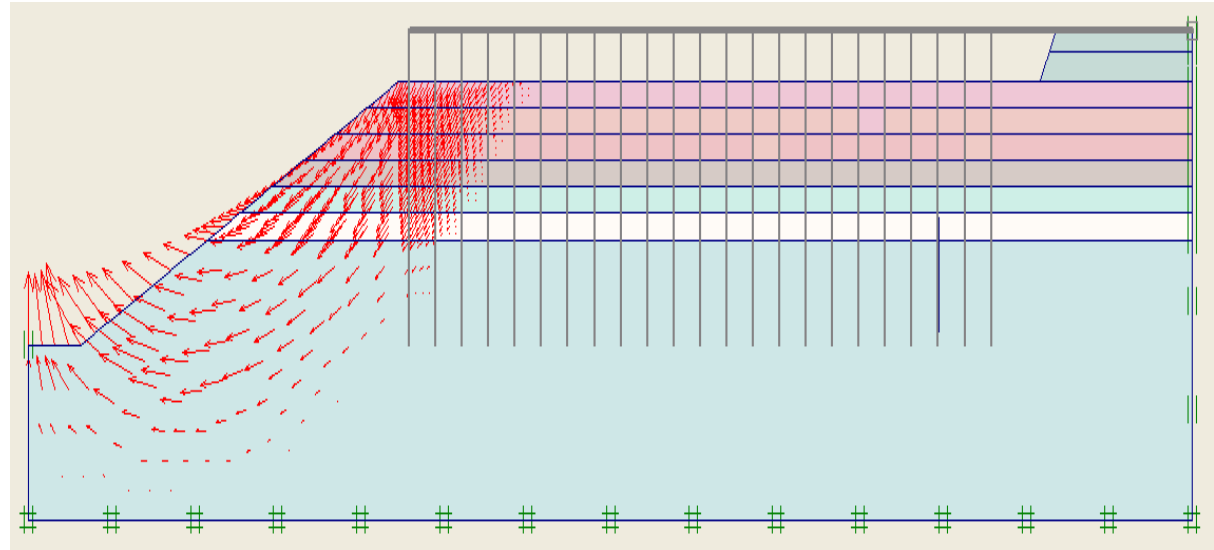

Gambar 23. Arah Keruntuhan yang Terjadi pada Keadaan Normal.

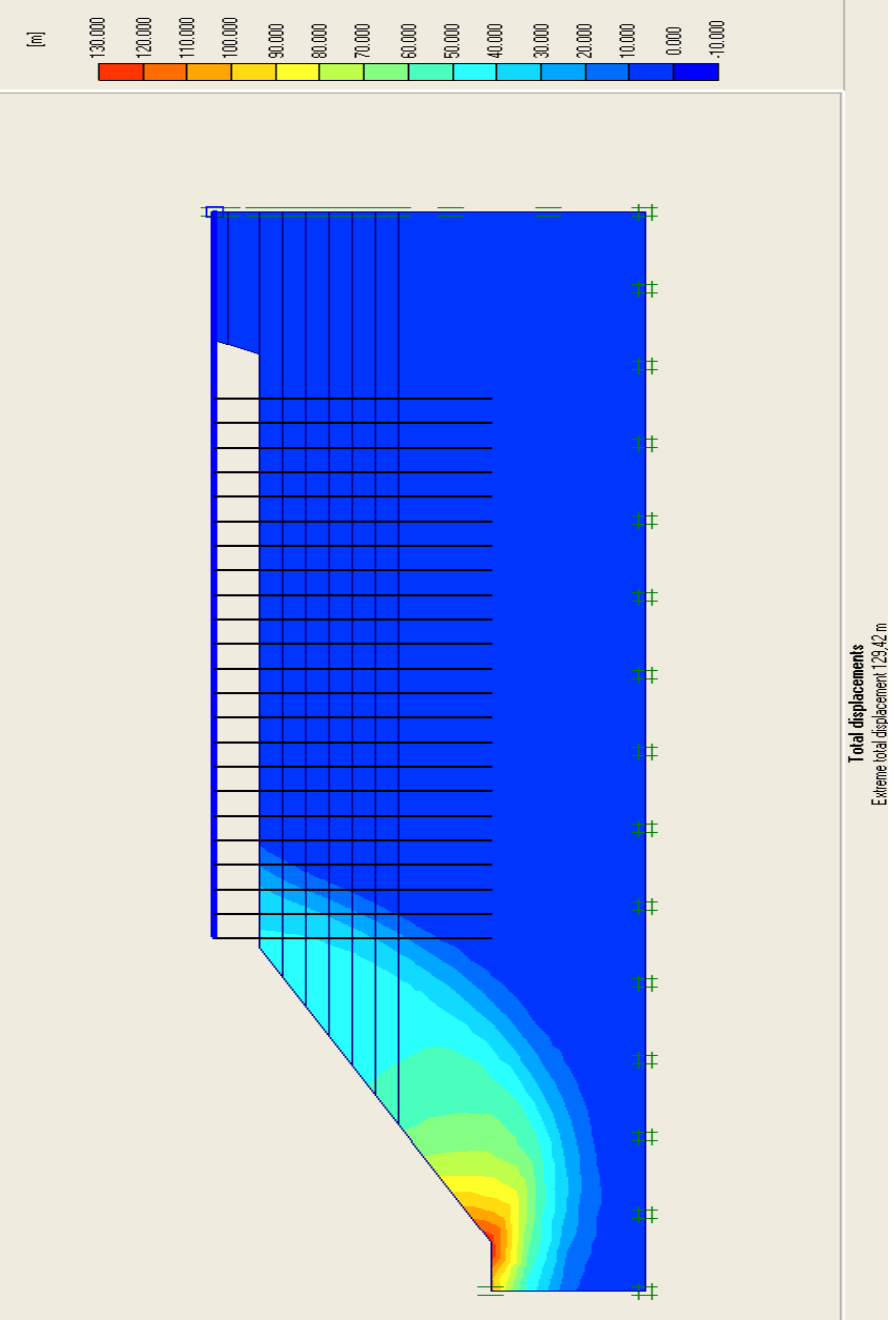

Gambar 24. Output deformasi Tanah karena Kenaikan Muka Air Laut. 
Berdasar hasil Plaxis, total pergeseran ekstrim akibat kenaikan muka air laut adalah 129,42 m. Hasil perhitungan stabilitas lereng dengan beban, penggunaan tiang pancang, balok karena proses penggalian saat kondisi naiknya permukaan air lautdengan menggunakan program Plaxis didapat $\Sigma$-Msf adalah 2,3251. Hasil perhitungan stabilitas lereng saat naiknya permukaan air laut dengan beban, penggunaan tiang pancang, balok karena seluruh proses konstruksi dengan menggunakan program Plaxis didapat $\Sigma$-Msf $=$ 2,3458. Lereng tersebut sangat aman, karena standar nilai faktor keamanan lereng adalah FK $\geq 1,2$. Selain $\Sigma$-Msf, dalam output juga dapat dilihat perpindahan dan tegangantegangan yang terjadi seperti terlihat pada Gambar 24 dan arah keruntuhan yang terjadi akibat kenaikan muka air laut dapat dilihat pada Gambar 25.

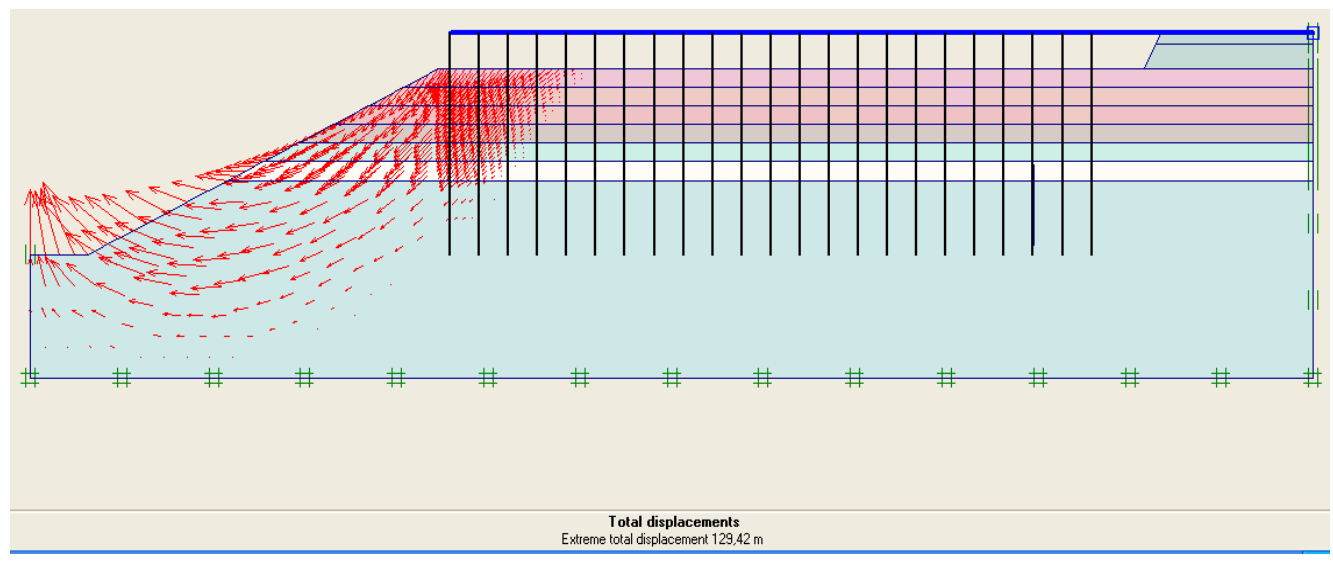

Gambar 25. Arah Keruntuhan yang Terjadi Akibat Kenaikan Muka Air Laut.

Rekapitulasi perhitungan stabilitas lereng pada kawasan Sambas, Pelabuhan Perikanan Nusantara Pemangkat, Kalimantan Barat ditunjukkan pada Tabel 1.

Tabel 1. Rekapitulasi Perhitungan Stabilitas Lereng

\begin{tabular}{|l|c|c|}
\hline \multicolumn{1}{|c|}{ Lereng } & Nilai $\mathbf{\Sigma}$ Msf & Kesimpulan \\
\hline Penggalian, Beban Air & 1,8579 & Aman \\
\hline $\begin{array}{l}\text { Dengan Beban, Penggalian, } \\
\text { Pemancangan, Pambalokan } \\
\text { (Keadaan Normal) }\end{array}$ & 2,3478 & Aman \\
\hline
\end{tabular}




\begin{tabular}{|l|c|c|}
\hline \multicolumn{2}{|c|}{ Tabel 4.lanjutan. } \\
\hline Dengan Beban, Penggalian, & & \\
Pemancangan, Pambalokan & & Aman \\
(Keadaan Kenaikan Muka Air Laut & 2,3458 & \\
- Akibat Pemanasan Global) & & \\
\hline
\end{tabular}

\section{SIMPULAN}

Simpulan yang diperoleh adalah sebagai berikut:

1. Faktor Keamanan untuk stabilitas lereng terhadap penggalian dan beban air laut adalah $1,2 \leq F S_{\text {Penggalian }}=1,8579$

2. Faktor Keamanan untuk stabilitas terhadap penggalian di bagi menjadi 2 bagian yaitu :

a. Faktor Keamanan untuk stabilitas terhadap penggalian normal $1,2 \leq F S_{\text {Penggalian }}=2,3235$

b. Faktor Keamanan untuk stabilitas terhadap penggalian kenaikan muka air laut akibat pemanasan global $1,2 \leq F S_{P e n g g a l i a n(P G)}=2,3251$

3. Faktor Keamanan untuk stabilitas terhadap penggalian, pemancangan, dan pembalokan di bagi menjadi 2 bagian yaitu :

a. Faktor Keamanan untuk stabilitas terhadap pemancangan dan pembalokan normal $1,2 \leq F S_{\text {Penggalian,Pemancangan,Pembalokan, }}=2,3478$

b. Faktor Keamanan untuk stabilitas terhadap pemancangan dan pembalokan naikny amuka air laut akibat pemanasan global, yaitu $1,2 \leq F S_{\text {Penggalian,Pemancangan,Pembalokan }(P G)}=2,3458$

Hasil dari faktor keamanan yang telah dianalisis dapat disimpulkan bahwa pemodelan tiang pancang pada geometri tanah dalam kondisi stabil dan aman dari bahaya erosi dan abrasi akibat kenaikan permukaan air laut.

\section{DAFTAR PUSTAKA}

1. Bowles, J. E., 1997. Foundation Analysis and Design. Erlangga. Jakarta 
2. Das, B.M., 2006. Principles of Geotechnical Engineering Fifth Edition, Nelson, Canada.

3. Shore Protection Manual, 1984. Departemen of The Army, Coastal Engineering Reseach Center.

4. Triatmodjo, B., 1999. Teknik Pantai. Edisi kedua. Beta offset. Yogyakarta.

5. Triatmodjo, B., 2009. Perencanaan Pelabuhan. Beta offset. Yogyakarta.

6. Verruijt, A., 2004. Soil mechanics, Delft. 